\title{
Maternal Hypothyroidism and Neonatal Obesity
}

\author{
Ahmed R.G* \\ Division of Anatomy and Embryology, Zoology Department, Faculty of Science, Beni-Suef University, Beni- \\ Suef, Egypt
}

*Corresponding Author: Ahmed R.G, Division of Anatomy and Embryology, Zoology Department, Faculty of Science, Beni-Suef University, Beni-Suef, Egypt, Email: ahmedragab08@gmail.com

\section{COMMENTARY}

A normal transportation of thyroid hormones (THs) from pregnant women to their fetuses/neonates is required for the normal development(El-bakry et al., 2010; Ahmed, 2011, 2012a,b, 2013, 2014, 2015a-c, 2016a-d, 2017a-v, 2018a-l; Ahmed and Ahmed, 2012; Ahmed et al., 2008; 2010; 2012; 2013a,b, 2014, 2015a,b, 2018a,b; Ahmed and Incerpi, 2013; Van Hercket al., 2013; Ahmed and ElGareib, 2014,Incerpi et al., 2014; Candelotti et al., 2015; De Vito et al., 2015; El-Ghareeb et al., 2016; Ahmed and El-Gareib, 2017), particularly the energy homeostasis, appetite, basal metabolic rate (BMR) and metabolic mechanisms (Laurberg et al., 2012; Kahr et al., 2016; Knight et al., 2016).On the other hand, several studies have shown a relationship between the subclinical hypothyroidism during gestation and an increase in the risk of gestational diabetes (Cleary-Goldman et al., 2008; Karakosta et al., 2012; Tudela et al., 2012; Chen et al., 2014; Toulis et al., 2014; Knight et al., 2016). In addition, mild maternal thyroid insufficiency (isolated hypothyroxinaemia; reduction in the level of free thyroxine (FT4) and an increase in the free triiodothyronine (FT3) to FT4 ratios) with poor obstetric outcomes during gestation can cause several adverse metabolic defects such as insulin resistance, glycaemia, obesity, and lipid profile disorders (hyperlipidaemia) (De Pergola et al., 2007; Roos et al., 2007; Tian et al., 2007; Cleary-Goldman et al., 2008; Garduno-Garcia et al., 2010; Bassols et al., 2011; Dennedy et al., 2012; Laurberg et al., 2012; Vrijkotte et al., 2012; Mehran et al., 2014; Roef et al., 2014). More interestingly, the association between the maternal hypo thyroxinaemia and obesity was observed in iodinedeficient pregnant women (Gowachirapant et al., 2014). It was supposed that obesity-induced the activities of peripheral deiodinases(Ds) increasing the energy expenditure, the conversion of FT4 to FT3 and eventually the FT3 to FT4 ratio (Haddow et al., 2015). Also, Kahr et al. (2016) reported the maternal and childhood obesity was increased with the variations in the levels of both maternal and neonatal THs. More importantly, ameliorating the function of the thyroid gland might be by improvement the lifestyle and diet (Reinehr and Andler, 2002; Reinehr et al., 2006; Laurberg et al., 2012), gastric bypass surgery (Fazylov et al., 2008) or gastric banding (Dall'Asta et al., 2010). Also, the complex interaction between the hypothalamic-pituitary-thyroid axis (HPTA) and adipocyte cytokines should be monitored to control the progress of the obesity (FeldtRasmussen, 2007; Boelen et al., 2008; Obregon, 2008; Endo et al., 2012; Sainsbury and Zhang, 2012).

The normal functions of the maternal thyroid gland during pregnancy may be vital for the body composition and the neonatal development. In addition, any disruption in the levels of THs during the gestation may cause obesity and suppress the neonatal development. Thus, women have to avoid the hypothyroxinemia and any excess in the body weight gain. Maintaining normoglycaemia during pregnancy may play an important role in a healthy life for the newborns. However, additional studies are essential to replicate these observations and to explore the harmful effects of maternofetal thyroid dysfunction (hypothyroidism or isolated hypothyroxinaemia) and obesity (adverse metabolic parameters) on long-term growth and neonatal development. Furthermore, the connection between the molecular and epidemiological studies is required. This argument is still ambiguous because of the difficulties of the direct observation of thyroid dysfunction on obesity. 


\section{REFERENCES}

[1] Ahmed, O.M., Abd El-Tawab, S.M., Ahmed, R.G., 2010. Effects of experimentally induced maternal hypothyroidism and hyperthyroidism on the development of rat offspring: I- The development of the thyroid hormonesneurotransmitters and adenosinergic system interactions. Int. J. Dev. Neurosci. 28, 437-454.

[2] Ahmed, O.M., Ahmed, R.G., 2012. Hypothyroidism. In A New Look At Hypothyroidism. Dr. D. Springer (Ed.), ISBN: 978-953-51-0020-1), In Tech Open Access Publisher, Chapter 1, pp. 1-20.

[3] Ahmed, O.M., Ahmed, R.G., El-Gareib, A.W., El-Bakry, A.M., Abd El-Tawaba, S.M., 2012. Effects of experimentally induced maternal hypothyroidism and hyperthyroidism on the development of rat offspring: II-The developmental pattern of neurons in relation to oxidative stress and antioxidant defense system. Int. J. Dev. Neurosci. 30, 517-537.

[4] Ahmed, O.M., El-Gareib, A.W., El-bakry, A.M., Abd El-Tawab, S.M., Ahmed, R.G., 2008. Thyroid hormones states and brain development interactions. Int. J. Dev. Neurosci. 26(2), 147-209. Review.

[5] Ahmed, R.G., 2011. Perinatal 2, 3, 7, 8tetrachlorodibenzo-p-dioxin exposure alters developmental neuroendocrine system. Food Chem. Toxicology, 49, 1276-1284.

[6] Ahmed, R.G., 2012a. Maternal-newborn thyroid dysfunction. In the Developmental Neuro endocrinology, pp. 1-369. Ed R.G. Ahmed. Germany: LAP LAMBERT Academic Publishing GmbH \& Co KG.

[7] Ahmed, R.G., 2012b. Maternal-fetal thyroid interactions, Thyroid Hormone, Dr. N.K. Agrawal (Ed.), ISBN: 978-953-51-0678-4, In Tech Open Access Publisher, Chapter 5, pp. 125-156.

[8] Ahmed, R.G., 2013. Early weaning PCB 95 exposure alters the neonatal endocrine system: thyroid adipokine dysfunction. J. Endocrinol. 219 (3), 205-215.

[9] Ahmed, R.G., 2014. Editorial: Do PCBs modify the thyroid-adipokine axis during development? Annals Thyroid Res. 1(1), 11-12.

[10] Ahmed, R.G., 2015a. Chapter 1: Hypothyroidism and brain development. In advances in hypothyroidism treatment. Avid Science Borsigstr.9, 10115 Berlin, Berlin, Germany. Avid Science Publications level 6, Melange Towers, Wing a, Hitec City, Hyderabad, Telangana, India. pp. 1-40.

[11] Ahmed, R.G., 2015b. Hypothyroidism and brain developmental players. Thyroid Research J. 8(2), 1-12.

[12] Ahmed, R.G., 2015c. Editorials and Commentary: Maternofetal thyroid action and brain development. J. of Advances in Biology; 7(1), 1207-1213.

[13] Ahmed, R.G., 2016a. Gestational dexamethasone alters fetal neuro endocrine axis. Toxicology Letters, 258, 46-54.

[14] Ahmed, R.G., 2016b. Neonatal polychlorinated biphenyls-induced endocrine dysfunction. Ann. Thyroid. Res. 2 (1), 34-35.

[15] Ahmed, R.G., 2016c. Maternal iodine deficiency and brain disorders. Endocrinol Metab.Syndr.5, 223.http://dx.doi.org/ 10.4172/ 2161-1017.1000223.

[16] Ahmed, R.G., 2016d. Maternal bisphenol A alters fetal endocrine system: Thyroid adipokine dysfunction. Food Chem. Toxicology, 95, 168-174.

[17] Ahmed, R.G., 2017a. Developmental thyroid diseases and GABAergic dysfunction. EC Neurology 8.1, 02-04.

[18] Ahmed, R.G., 2017b. Hyperthyroidism and developmental dysfunction. Arch Med. 9, 4.

[19] Ahmed, R.G., 2017c. Anti-thyroid drugs may be at higher risk for perinatal thyroid disease. EC Pharmacology and Toxicology 4.4, 140142.

[20] Ahmed, R.G., 2017d. Perinatal hypothyroidism and cytoskeleton dysfunction. Endocrinol Metab Syndr 6, 271.doi:10.4172/2161-1017. 1000271

[21] Ahmed, R.G., 2017e. Developmental thyroid diseases and monoaminergic dysfunction. Advances in Applied Science Research 8(3), 0110.

[22] Ahmed, R.G., 2017f. Hypothyroidism and brain development. J. Anim Res Nutr.2 (2), 13.

[23] Ahmed, R.G., 2017g. Antiepileptic drugs and developmental neuroendocrine dysfunction: Every why has A Wherefore. Arch Med 9(6), 2.

[24] Ahmed, R.G., 2017h. Gestational prooxidantantioxidant imbalance may be at higher risk for postpartum thyroid disease. Endocrinol Metab Syndr 6, 279. doi:10.4172/2161-1017.1000279.

[25] Ahmed, R.G., 2017i. Synergistic actions of thyroid-adipokines axis during development. Endocrinol Metab Syndr 6, 280.doi:10.4172/ 2161-1017.1000280.

[26] Ahmed, R.G., 2017j. Thyroid-insulin dysfunction during development. International Journal of Research Studies in Zoology 3(4), 73-75. DOI: http://dx.doi.org/10.20431/2454941X.0304010.

[27] Ahmed, R.G., 2017k. Developmental thyroid diseases and cholinergic imbalance. International Journal of Research Studies in Zoology 3(4), 7072. DOI: http://dx.doi.org/ 10.20431/2454-941 X.0304009.

[28] Ahmed, R.G., 20171. Thyroid diseases and developmental adenosinergic imbalance. Int $\mathbf{J}$ Clin Endocrinol 1(2), 053-055. 
[29] Ahmed, R.G., 2017m. Maternal anticancer drugs and fetal neuroendocrine dysfunction in experimental animals. Endocrinol Metab Syndr 6, 281.doi:10.4172/2161-1017.1000281.

[30] Ahmed, R.G., 2017n. Letter: Gestational dexamethasone may be at higher risk for thyroid disease developing peripartum. Open Journal of Biomedical \& Life Sciences (Ojbili) 3(2), 01-06.

[31] Ahmed, R.G., 2017o. Deiodinases and developmental hypothyroidism. EC Nutrition 11.5, 183-185.

[32] Ahmed, R.G., 2017p. Maternofetal thyroid hormones and risk of diabetes. Int. J. of Res. Studies in Medical and Health Sciences 2(10), 18-21.

[33] Ahmed, R.G., 2017r. Association between hypothyroidism and renal dysfunctions. International Journal of Research Studies in Medical and Health Sciences 2(11), 1-4.

[34] Ahmed, R.G., 2017s. Maternal hypothyroidism and lung dysfunction. International Journal of Research Studies in Medical and Health Sciences 2(11), 8-11.

[35] Ahmed, R.G., 2017t. Endocrine disruptors; possible mechanisms for inducing developmental disorders. International journal of basic science in medicine (IJBSM) 2(4), 157-160.

[36] Ahmed, R.G., 2017u.Maternal thyroid hormones trajectories and neonatal behavioral disorders. ARC Journal of Diabetes and Endocrinology 3(2), 18-21.

[37] Ahmed, R.G., 2017v.Maternal thyroid dysfunction and neonatal cardiac disorders. Insights Biol Med. 1, 092-096.

[38] Ahmed, R.G., 2018a. Maternal hypothyroidism and neonatal testicular dysfunction. International Journal of Research Studies in Medical and Health Sciences 3(1), 8-12.

[39] Ahmed, R.G., 2018b. Maternal hypothyroidism and neonatal depression: Current perspective. International Journal of Research Studies in Zoology 4(1), 6-10. DOI: http://dx.doi.org/ 10. 20431/2454-941X.0401002.

[40] Ahmed, R.G., 2018c. Non-genomic actions of thyroid hormones during development. App Clin Pharmacol Toxicol: ACPT-108. DOI: 10. 29011/ACPT-109. 100008.

[41] Ahmed, R.G., 2018d. Maternal thyroid function and placental hemodynamic. ARC Journal of Animal and Veterinary Sciences 4(1), 9-13. DOI: http://dx.doi.org/10.20431/2455-2518.04 01002.

[42] Ahmed, R.G., 2018e. Interactions between thyroid and growth factors during development. ARC Journal of Diabetes and Endocrinology 4(1), 1-4. DOI: http://dx.doi.org/10.20431/245 5-5983.0401001.
[43] Ahmed, R.G., 2018f. Maternal thyroid hormones and neonatal appetite. ARC Journal of Nutrition and Growth 4(1), 18-22. DOI: http://dx.doi.org/10.20431/2455-2550.0401005.

[44] Ahmed, R.G., 2018g. Genomic actions of thyroid hormones during development. ARC Journal of Diabetes and Endocrinology 4(1), 58. DOI: http://dx.doi.org/10.20431/2455-5983. 0401002 .

[45] Ahmed, R.G., 2018h. Dysfunction of maternal thyroid hormones and psychiatric symptoms. American Research Journal of Endocrinology. 2(1), 1-6.

[46] Ahmed, R.G., 2018i. Is there a connection between maternal hypothyroidism and developing autism spectrum disorders? ARC Journal of Neuroscience 3(1), 5-8. DOI: http://dx.doi.org/ 10.20431/2456-057X. 0301002.

[47] Ahmed, R.G., 2018j. Maternal thyroid dysfunctions and neonatal bone mal development.American Research Journal of Endocrinology (in press) $\mathrm{xx}-\mathrm{xxx}$.

[48] Ahmed, R.G., 2018k. Maternal thyroid disorders and risk of neonatal seizure: Current perspective. ARC Journal of Neuroscience (in press) $\mathrm{XX}-\mathrm{XX}$.

[49] Ahmed, R.G., 20181. Gestational dioxin acts as developing neuroendocrine-disruptor. EC Pharmacology and Toxicology (in press) xx-xx.

[50] Ahmed, R.G., Abdel-Latif, M., Ahmed F., 2015a.Protective effects of GM-CSF in experimental neonatal hypothyroidism. International Immuno pharmacology 29, 538-543.

[51] Ahmed, R.G., Abdel-Latif, M., Mahdi, E., ElNesr, K., 2015b. Immune stimulation improves endocrine and neural fetal outcomes in a model of maternofetal thyrotoxicosis. Int. Immuno pharmacol. 29, 714-721.

[52] Ahmed, R.G., Davis, P.J., Davis, F.B., De Vito, P., Farias, R.N., Luly, P., Pedersen, J.Z., Incerpi, S., 2013a. Nongenomic actions of thyroid hormones: from basic research to clinical applications. An update. Immunology, Endocrine \& Metabolic Agents in Medicinal Chemistry, 13(1), 46-59.

[53] Ahmed, R.G., El-Gareib, A.W. 2014. Lactating PTU exposure: I- Alters thyroid-neural axis in neonatal cerebellum. Eur. J. of Biol. and Medical Sci. Res. 2(1), 1-16.

[54] Ahmed, R.G., El-Gareib, A.W., 2017. Maternal carbamazepine alters fetal neuroendocrinecytokines axis. Toxicology 382, 59-66.

[55] Ahmed, R.G., El-Gareib, A.W., Incerpi, S., 2014. Lactating PTU exposure: II- Alters thyroid-axis and prooxidant-antioxidant balance in neonatal cerebellum. Int. Res. J. of Natural Sciences 2(1), 1-20.

[56] Ahmed, R.G.,El-Gareib, A.W., Shaker, H.M., 2018a.Gestational 3,3',4,4',5-pentachlorobiphenyl 
(PCB 126) exposure disrupts fetoplacental unit: Fetal thyroid-cytokines dysfunction. Life Sciences 192, 213-220.

[57] Ahmed, R.G.,Walaa G.H., Asmaa F.S., 2018 b. Suppressive effects of neonatal bisphenol A on the neuroendocrine system. Toxicology and Industrial Health Journal (in press).

[58] Ahmed, R.G., Incerpi, S., 2013. Gestational doxorubicin alters fetal thyroid-brain axis. Int. J. Devl. Neuroscience 31, 96-104.

[59] Ahmed, R.G., Incerpi, S., Ahmed, F., Gaber, A., 2013b. The developmental and physiological interactions between free radicals and antioxidant: Effect of environmental pollutants. J. of Natural Sci. Res. 3(13), 74-110.

[60] Bassols, J., Prats-Puig, A., Soriano-Rodriguez, P., Garcia-Gonzalez, M.M., Reid, J., MartinezPascual, M., Mateos-Comeron, F., de Zegher, F., Ibanez, L., Lopez-Bermejo, A., 2011. Lower free thyroxin associates with a less favorable metabolic phenotype in healthy pregnant women. Journal of Endocrinology and Metabolism 96, 3717-3723.

[61] Boelen, A., Wiersinga, W.M., Fliers, E., 2008. Fasting induced changes in the hypothalamuspituitary-thyroid axis. Thyroid 18, 123-129.

[62] Candelotti, E., De Vito, P., Ahmed, R.G., Luly, P., Davis, P.J., Pedersen, J.Z., Lin, H-Y., Incerpi, I., 2015. Thyroid hormones crosstalk with growth factors: Old facts and new hypotheses. Immun., Endoc. \& Metab. Agents in Med. Chem., 15, 71-85.

[63] Chen, L.M., Du, W.J., Dai, J., Zhang, Q., Si, G.X., Yang, H., Ye, E.L., Chen, Q.S., Yu, L.C., Zhang, C., 2014. Effects of subclinical hypothyroidism on maternal and perinatal outcomes during pregnancy: a single-center cohort study of a Chinese population. PLoS ONE 9, e109364.

[64] Cleary-Goldman, J., Malone, F.D., LambertMesserlian, G., Sullivan, L., Canick, J., Porter, T.F., Luthy, D., Gross, S., Bianchi, D.W., D'Alton, M.E., 2008. Maternal thyroid hypofunction and pregnancy outcome. Obstetrics and Gynecology 112, 85-92.

[65] Dall'Asta, C., Paganelli, M., Morabito, A., Vedani, P., Barbieri, M., Paolisso, G., Folli, F., Pontiroli, A.E., 2010. Weight loss through gastric banding: effects on TSH and thyroid hormones in obese subjects with normal thyroid function. Obesity 18, 854-857.

[66] De Pergola, G., Ciampolillo, A., Paolotti, S., Trerotoli, P., Giorgino, R., 2007. Free triiodothyronine and thyroid stimulating hormone are directly associated with waist circumference, independently of insulin resistance, metabolic parameters and blood pressure in overweight and obese women. Clinical Endocrinology 67, 265-269.

[67] De Vito, P., Candelotti, E., Ahmed, R.G., Luly, P., Davis, P.J., Incerpi, S., Pedersen, J.Z.,
2015.Role of thyroid hormones in insulin resistance and diabetes. Immun., Endoc. \& Metab. Agents in Med. Chem., 15, 86-93.

[68] Dennedy, M.C., Avalos, G., O’Reilly, M.W., O’Sullivan, E.P., Gaffney, G., Dunne, F., 2012. ATLANTIC-DIP: raised maternal body mass index (BMI) adversely affects maternal and fetal outcomes in glucose-tolerant women according to International Association of Diabetes and Pregnancy Study Groups (IADPSG) criteria. Journal of Endocrinology and Metabolism 97, E608-E612.

[69] El-bakry, A.M., El-Ghareeb, A.W.,Ahmed, R.G., 2010.Comparative study of the effects of experimentally-induced hypothyroidism and hyperthyroidism in some brain regions in albino rats.Int. J. Dev. Neurosci. 28, 371-389.

[70] El-Ghareeb, A.A., El-Bakry, A.M., Ahmed, R.G., Gaber, A., 2016. Effects of zinc supplementation in neonatal hypothyroidism and cerebellar distortion induced by maternal carbimazole. Asian Journal of Applied Sciences 4(04), 1030-1040.

[71] Endo, T., Kobayashi, T., 2012. Expression of functional TSH receptor in white adipose tissues of hyt/hyt mice induces lipolysis in vivo. Am J Physiol Endocrinol Metab 302, 1569-1575.

[72] Fazylov, R., Soto, E., Cohen, S., Merola, S., 2008. Laparoscopic Roux-en-Y gastric bypass surgery on morbidly obese patients with hypothyroidism. ObesSurg 18, 644-647.

[73] Feldt-Rasmussen, U., 2007.Thyroid and leptin. Thyroid 17, 413-419.

[74] Garduno-Garcia Jde, J., Alvirde-Garcia, U., Lopez-Carrasco, G., Padilla Mendoza, M.E., Mehta, R., Arellano-Campos, O., Choza, R., Sauque, L., Garay-Sevilla, M.E., Malacara, J.M., Gomez-Perez, F.J., Aguilar-Salinas, C.A., 2010. TSH and free thyroxine concentrations are associated with differing metabolic markers in euthyroid subjects. European Journal of Endocrinology 163, 273-278.

[75] Gowachirapant, S., Melse-Boonstra, A., Winichagoon, P., Zimmermann, M.B., 2014. Overweight increases risk of first trimester hypothyroxinaemia in iodine-deficient pregnant women. Maternal \& Child Nutrition 10, 61-71.

[76] Haddow, J.E., Neveux, L.M., Palomaki, G.E., Lambert-Messerlian, G., Malone, F.D., D’Alton, M.E., 2015. An inverse relationship between weight and free thyroxine during early gestation among women treated for hypothyroidism. Thyroid 25, 949-953.

[77] Incerpi, S., Hsieh, M-T., Lin, H-Y., Cheng, G-Y., De Vito, P., Fiore, A.M., Ahmed, R.G., Salvia, R., Candelotti, E., Leone, S., Luly, P., Pedersen, J.Z., Davis, F.B., Davis, P.J., 2014. Thyroid hormone inhibition in L6 myoblasts of IGF-I-mediated glucose uptake and proliferation: new roles for 
integrin $\alpha v \beta 3$. Am. J. Physiol. Cell Physiol. 307, C150-C161.

[78] Kahr, M.K., Antony, K.M., DelBeccaro, M., Hu, M., Aagaard, K.M., Suter, M.A., 2016. Increasing maternal obesity is associated with alterations in both maternal and neonatal thyroid hormone levels. Clinical Endocrinology 84, 551-557.

[79] Karakosta, P., Alegakis, D., Georgiou, V., Roumeliotaki, T., Fthenou, E., Vassilaki, M., Boumpas, D., Castanas, E., Kogevinas, M., Chatzi, L., 2012. Thyroid dysfunction and auto antibodies in early pregnancy are associated with increased risk of gestational diabetes and adverse birth outcomes. Journal of Endocrinology and Metabolism 97, 4464-4472.

[80] Knight, B.A., Shields, B.M., Hattersley, A.T., Vaidya, B., 2016. Maternal hypothyroxinaemia in pregnancy is associated with obesity and adverse maternal metabolic parameters. European Journal of Endocrinology 174, 51-57.

[81] Laurberg, P., Knudsen, N., Andersen, S., Carle, A., Pedersen, I.B., Karmisholt, J., 2012.Thyroid function and obesity. European Thyroid Journal 1, 159-167.

[82] Laurberg, P., Knudsen, N., Andersen, S., Carlé, A., Pedersen, I.B., Karmisholt, J., 2012.Thyroid function and obesity.Eur Thyroid J 1, 159-167.

[83] Mehran, L., Amouzegar, A., Tohidi, M., Moayedi, M., Azizi, F., 2014. Serum free thyroxine concentration is associated with metabolic syndrome in euthyroid subjects. Thyroid 24, 1566-1574.

[84] Obregon, M.J., 2008. Thyroid hormone and adipocyte differentiation. Thyroid 18, 185-195.

[85] Reinehr, T., Andler, W., 2002.Thyroid hormones before and after weight loss in obesity. Arch Dis Child 87, 320-323.

[86] Reinehr, T., de Sousa, G., Andler, W., 2006. Hyperthyrotropinemia in obese children is reversible after weight loss and is not related to lipids. J Clin Endocrinol Metab 91, 3088-3091.
[87] Roef, G.L., Rietzschel, E.R., Van Daele, C.M., Taes, Y.E., De Buyzere, M.L., Gillebert, T.C., Kaufman, J.M., 2014. Triiodothyronine and free thyroxine levels are differentially associated with metabolic profile and adiposity related cardiovascular risk markers in euthyroid middle-aged subjects. Thyroid 24, 223-231.

[88] Roos, A., Bakker, S.J., Links, T.P., Gans, R.O., Wolffenbuttel, B.H., 2007. Thyroid function is associated with components of the metabolic syndrome in euthyroid subjects. Journal of Clinical Endocrinology and Metabolism 92, 491-496.

[89] Sainsbury, A., Zhang, L., 2012. Role of the hypothalamus in the neuroendocrine regulation of body weight and composition during energy deficit. Obes Rev 13, 234-257.

[90] Tian, L., Shen, H., Lu, Q., Norman, R.J., Wang, J., 2007. Insulin resistance increases the risk of spontaneous abortion after assisted reproduction technology treatment. Journal of Endocrinology and Metabolism 92, 1430-1433.

[91] Toulis, K.A., Stagnaro-Green, A., Negro, R., 2014. Maternal subclinical hypothyroidsm and gestational diabetes mellitus: a meta-analysis. Endocrine Practice 20, 703-714.

[92] Tudela, C.M., Casey, B.M., McIntire, D.D., Cunningham, F.G., 2012. Relationship of subclinical thyroid disease to the incidence of gestational diabetes. Obstetrics and Gynecology 119, 983-988.

[93] Van Herck, S.L.J., Geysens, S., Bald, E., Chwatko, G., Delezie, E., Dianati, E., Ahmed, R.G., Darras, V.M., 2013.Maternal transfer of methimazole and effects on thyroid hormone availability in embryonic tissues. Endocrinol. 218, 105-115.

[94] Vrijkotte, T.G., Krukziener, N., Hutten, B.A., Vollebregt, K.C., van Eijsden, M., Twickler, M.B., 2012. Maternal lipid profile during early pregnancy and pregnancy complications and outcomes: the ABCD study. Journal of Endocrinology and Metabolism 97, 3917-3925.

Citation: Ahmed R.G. Maternal Hypothyroidism and Neonatal Obesity. ARC Journal of Diabetes and Endocrinology. 2018; 4(2):1-5. doi:dx.doi.org/10.20431/2455-5983.0402001.

Copyright: () 2018 Authors. This is an open-access article distributed under the terms of the Creative Commons Attribution License, which permits unrestricted use, distribution, and reproduction in any medium, provided the original author and source are credited. 